\title{
A Need Analysis For Developing Integrated Stem Course Training Module For Pre-Service Mathematics Teachers
}

\author{
Usman Galadima, Zaleha Ismail, Norulhuda Ismail
}

\begin{abstract}
The purpose of this paper is to present the need to develop the integrated Science, Technology, Engineering and Mathematics (iSTEM) course training module for preparing the pre-service mathematics teachers' readiness in teaching the iSTEM course in their future classroom instruction. In this paper, the researchers present the data for the study collected qualitatively using semi-structured interview questions. Purposive sampling was used in choosing 6 university lecturers in Nigeria for conducting the interview to identify and seek their insights regarding the need for iSTEM course training and module for teaching iSTEM course. An interview data collected was transcribed and inductively analysed using an exploratory content analysis approach in which five main themes have been identified, namely: (i) pedagogical knowledge; (ii) content knowledge; (iii) conception of the iSTEM; (iv) instructional strategy and (v) curricula knowledge for teaching iSTEM course. The results of this study indicated that all the six interview participants responded that they have no idea and had insufficient knowledge about the teaching of integrated STEM course. Moreover, the lecturers indicated that they were not exposed to the iSTEM course at all. The findings revealed that there is a need for the iSTEM course training and development of the iSTEM teaching module in helping the pre-service mathematics teachers' readiness in teaching the iSTEM course. Based on the findings, the researchers recommended suitable iSTEM course training module to prepare the pre-service mathematics teachers' readiness in teaching iSTEM course could be integrated into the teacher education curriculum in Nigeria.
\end{abstract}

Index Terms: Integrated STEM, Pre-service Mathematics Teachers, Need Analysis, Training Module.

\section{INTRODUCTION}

Integrated Science, Technology, Engineering, and Mathematics (iSTEM) is a new approach that emphasises application linking all the STEM disciplines. This approach is receiving increasing global attention to help in tackling the 21st-century challenge to national growth and development. Ideally, the trend in the whole world is moving towards iSTEM teaching and learning (Evans, 2015). In line with this, the developed nations viewed iSTEM teaching and learning as cohesive and focused on the interconnectivity of all the STEM disciplines (Fogarty, 1991; Stohlmann et al., 2012).

Revised Manuscript Received on April 19, 2019.

Usman Galadima, Department of Science Education, Sokoto State University, Sokoto, Nigeria.

Zaleha Ismail, Department of Science, Mathematics and Creative Multimedia Education, Universiti Teknologi Malaysia.

Norulhuda Ismail, Department of Science, Mathematics and Creative Multimedia Education, Universiti Teknologi Malaysia
The reality in Nigeria is that, in spite of the importance of iSTEM education to the development of the nation at large, the stakeholders were only familiar with the individual STEM discipline. As such, each of the STEM individual disciplines is taught separately as silos and distinct field of study [1]. However, over the years in Nigeria, there are calls from stakeholders in education for action to integrate STEM disciplines into the Nigerian curriculum due to the lack of implementation of the iSTEM in the country. The situation is that the pre-service mathematics teachers are not exposed to the iSTEM course and are only receiving training in the single and separate field of STEM (Okpala, 2012; Ugo, 2016).

The consequences associated with separate disciplines instruction is that it is likely that single discipline pedagogy may not help the pre-service mathematics teachers to understand the connection between and within the STEM disciplines. Adversely, if the iSTEM education is not implemented in Nigeria, it will affect the productivity of the learners. Thus, for the pre-service mathematics teachers to move from their existing approach of teaching separate STEM subjects to promoting the iSTEM course in Nigeria, there must be a strong focus on teacher preparation course on iSTEM education (Muhammad, 2017; Yusha'u, 2015).

\section{A. The Need for the iSTEM Course Training}

Following the above combined problems prompted the researchers to carry out this study on the need to develop the iSTEM course training and teaching module for preparing the pre-service mathematics teachers' readiness in teaching the iSTEM course in their future classroom instruction. The reason for employing the pre-service mathematics teachers is due to their capability and willingness to embrace change. This assertion aligns with Evans (2015) statement that preservice teachers as the future iSTEM education leaders can be at the forefront in the STEM movement, particularly with a meaningful experience within their teacher preparation course for integrating STEM course into their instructions. The iSTEM course, if implemented will be able to prepare and promote the pre-service mathematics teachers' readiness to connect the STEM disciplines into one cohesive teaching and learning pedagogy for solving the real-world problems that would lead the road for the effective and better understanding the connection of mathematics between and

Published By:

Blue Eyes Intelligence Engineering

\& Sciences Publication 
among the STEM disciplines.

\section{B. Purpose of the Study}

The purpose of this research was to present a study on the need to develop the iSTEM course training module for teaching the iSTEM course in Nigeria.

\section{LITERATURE REVIEW}

This 21st-century competence demand human resources engineering design, science, technology, and mathematics to integrate the four STEM disciplines. In this era of competent human resources, there is a need for workers to have the knowledge of mathematics skills and science, creativity, expertise in communication and information technology, and the capability to solve complex real-world problems [2]. In relation to solving real-world problems, single disciplines prevent the preservice mathematics teachers from building the needed competencies and connection between and among the four fields of STEM [3].

In essence, the results from the iSTEM 2017 conference clearly indicated that the iSTEM should be guided by meaningful engagement and constructivist principles [4]. Specifically utilising the principles of the importance of iSTEM into the instruction, demonstrated how the STEM skills can be integrated into interdisciplinary instruction, and increase the commitment, confidence and readiness level of pre-service teachers for integrating STEM into their own instructions [4]. In the more recent researches of the iSTEM such as Dooley, Atkinson-Hamilton [4], Honey, Pearson [5], Evans [6], Heba, Mansour [7] it was indicated that iSTEM is an interdisciplinary strategy that is more focused and addresses a specific problem.

Furthermore, it is essential that curriculum developers, teacher educators and scientific institutions recognise the need for an iSTEM course for preparing future innovators, creative problem solvers, qualified workers that can contribute immensely to the global economy (Roberts, 2012). In addition to this, most of the researchers indicated that, the iSTEM curriculum offers favourable circumstances for more relevant, integrated, coherent, and more for learners stimulating experiences [8-11].

Building on the above needs of the iSTEM course, the iSTEM teaching and learning nowadays received attention and widely emphasises aspects of practicality and reality in which students can learn mathematics and science through the application of engineering and technology in realistic and meaningful ways around the world [12]. The push for the iSTEM Education comes from the continually growing demand for the required STEM skills to meet present and future global economic and social challenges [13, 14]. Additionally, according to Stohlmann, Moore [15], there are numerous approaches and needs that teachers are required to effectively teach iSTEM education such as knowledge, experience, and background. Also, Stohlmann, Moore [15], detailed the importance of supporting teachers; teaching practice on teaching integrated mathematics and science provides a good basis for iSTEM education; teachers' beliefs about their capabilities to produce the desired effect on students learning, and materials needed to implement STEM integration. These are vital for the future success of students preparing the pre-service mathematics teachers' readiness in

as they build their careers in STEM fields and may improve their motivation, interest, performance in mathematics and science.

To this end, due to the inability of empirical research on integrated STEM in Nigeria, this study serves as an excellent starting point and preamble for the researchers who wish to drive the future of pre-service teachers for iSTEM teaching and learning. Likewise, this study is needed as a way for framing future research and also guide the teacher educators with the necessary information that would be of importance while hoping to conduct research on iSTEM teaching module for fruitful collaboration [16] in addressing pre-service teachers with STEM integration.

\section{A. Theoretical Framework of this Study}

The theoretical framework that guided this study is Pedagogical Content Knowledge (PCK) based on the ideas of $[17,18]$. This study connected to the theory of PCK because of its importance in the training and preparing the pre-service mathematics teachers to teach the iSTEM course. The concept of PCK was developed by Shulman Lee in his research in the year 1986 and since then several researchers used the concept to explain the components necessary to teach the iSTEM course effectively. However, the five components of PCK employed in this study were built upon on the study of Shulman [17] and extended by Grossman [19] and Magnusson, Krajcik [20] research includes: Pedagogical Knowledge; Content Knowledge; Knowledge of instructional strategy; Knowledge of Curricula; and Knowledge of pre-service mathematics teacher's conception for teaching iSTEM course. In relating PCK to iSTEM, if pre-service mathematics teachers lack either iSTEM PK or CK, then they lack the iSTEM PCK that enables them to teach iSTEM effectively [21]. The theoretical framework derived for this study can be seen in Figure 1 below.

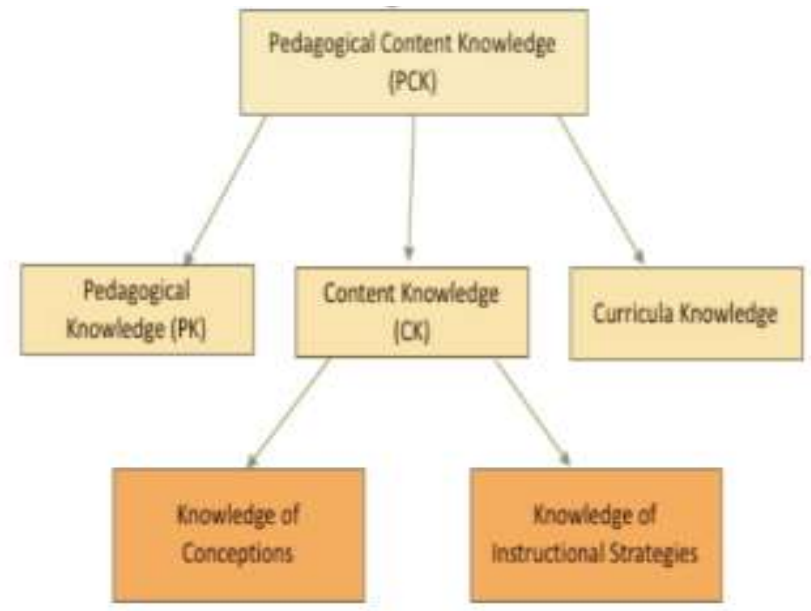

Fig. 1: Shulman [17], Shulman [18] categories of PCK and subcategories of CK by Shahali, Halim [21].

Shulman [18] argued that PCK is the knowledge base of teaching and transforming knowledge into adaptive instruction; the essential way to determine the knowledge base of teaching depends on the incorporating of content and pedagogy; in the capacity of teachers to transform the 
content knowledge acquires into a structure that are pedagogically powerful to teach all students to reason and think critically in solving problems; and this teaching adaptive necessary understanding and which begin with what is to be learned and the manner on how it is to be taught by representing ideas so that the learner can come to learn, the slow learner can comprehend and discern, and the novice can become veteran adept [18]. So, Pedagogical knowledge incorporates teaching approaches, such as handson activities, inquiry-based learning and micro-teaching in order to build conceptual understanding of teaching strategies, where content knowledge and Pedagogical knowledge are linked. In relating the iSTEM to PCK, if the pre-service mathematics teachers lack either iSTEM content knowledge or iSTEM pedagogical knowledge, then likely they will lack the iSTEM-PCK knowledge that prepared them to teach iSTEM to their students effectively [22]. Consequently, content knowledge includes the actual knowledge of the content that is to be learned or taught, that has the potential to strongly influence how pre-service mathematics teachers represent the content and design a learning experience and strategies to support the learners about the content to be taught. In order to ensure that teachers are successful, it is important that they receive support for developing their content knowledge to be able to effectively teach integrated STEM [15].

However, the knowledge of conceptions for teaching has been identified as general mental structures that represent frameworks for the way teachers interpret and interact with the teaching environment [23]. Conceptions influence our behaviour and according to Pratt [23], it mediates the response to situations. Additionally, some studies have shown that the perception of teachers that can be defined as their way of conceiving classroom work in connection to teaching and learning of students [24] has an impact on their science and classroom practices in mathematics [25]. Because there are different ways to conceptualize iSTEM education [26-28] and because conceptions influence behaviour [23] examining teachers' conceptions of an iSTEM is important and particularly as it relates to curriculum development and classroom practices.

Additionally, Knowledge of instructional strategies in teaching iSTEM improves the pre-service mathematics teacher practice to explicitly address teaching strategies necessary to know the ways to incorporate the pedagogical knowledge and content knowledge in order to have the ability to teach the iSTEM course. Moreover, Knowledge of instructional strategies is a set of activities systematically employed by the teachers that involve specific steps to get learners outcome [18]. Also, According to [29, 30] defined instructional strategies as a meaningful way in which the teacher understands and uses a variety of instructional strategies to develop a deep understanding of content areas and build skills in applying the knowledge.

Conclusively, curricular knowledge is also a knowledge of what to teach to a particular group of learners. Though educational theorists have debated how to best to define the term curriculum [31]. The knowledge of curriculum is commonly not only define what is to be taught but also set out or at least advise on the way teachers should teach, it requires consideration of the learners potential and the definition adopted here is a plan for learning as proposed by Ring [31]. Building on an integrated curriculum required that teachers are responsible to create challenging, meaningful tasks and fun that help learners connect to the content. Further integration of contents in the fields of mathematics and science $[10,11,32-36]$ to enhance the meaning of what is taught reduce the need to get everything covered and to make natural and holistic learning. The Teachers whose education tends to be more general in its scope, can feel overwhelmed by the amount of content knowledge required when implementing iSTEM curricula [37]. While various teachers understand the benefits to both improve and implement an iSTEM curriculum and content knowledge. Moreover, professional development helps teachers to understand the opportunities available are limited in their classroom on how to integrate STEM disciplines $[38,39]$.

\section{METHODOLOGY}

In this study, a qualitative research design using semistructured interview questions was used to explore the need to develop the iSTEM course training module for the preservice mathematics teachers. The semi-structured interviews are used across disciplines because it gives the respondents the opportunity to spell out their viewpoints on the phenomenon under study [40]. Purposive sampling was used in choosing 6 university lecturers (donated by R1, R2, R3, R4, R5 and R6) who are also mathematics and science lecturers. The lecturers were prominent in the field of STEM education in Nigeria for conducting this study to identify and seek their insights regarding the need for the iSTEM course training and module for teaching the iSTEM course. The researchers utilised 20 minutes each to interviewed the six respondents. The interviews data collected was tabulated based on the questionnaire items and analysed inductively [41] using the content analysis approach [42]. According to Creswell [40], an interview data generated can be transcribed and inductively categorised using qualitative content analysis approach. The qualitative content analysis approach was employed in this study because it is one among the several qualitative methods used to make sense out of textual data into a summary format [43] and, as such, the data collected for this study is also a raw text data.

\section{RESULTS AND FINDINGS}

In this study six university lecturers were interviewed to gain insight about the need for teaching and learning of iSTEM course. The interview questions and responses are shown in Table 1 below. The researcher introduced and briefed the lecturers on the concepts of iSTEM but their responses showed that they have no idea and knowledge about the concept of iSTEM. Also, they pointed out that they have insufficient knowledge in teaching iSTEM course. The interviews also revealed that the teachers were not exposed to the integration of various disciplines as there are no guidelines for teaching iSTEM provided by the National Universities Commission (NUC) for the teaching of 
integrated STEM course. Likewise, most respondents also stated that there are no iSTEM teaching and learning syllabus or teaching module available for the teaching of iSTEM provided by the NUC. Additionally, they feel unprepared to connect several STEM disciplines together and they had insufficient knowledge for teaching the iSTEM course. Consequently, the participants revealed that they have no idea about combining two or more disciplines and they are still teaching individual discipline. The results of this study supported the need for the iSTEM course training and the development of iSTEM course module. The interview data set resulted in the identification of five main themes which includes: pedagogical knowledge, content knowledge, curricula knowledge, the iSTEM conceptions, and instructional strategies for teaching the iSTEM course.

Table 1. Interview Questions and Responses for the Need Analysis

\begin{tabular}{|c|c|c|c|}
\hline $\mathrm{S} / \mathrm{N}$ & Question & Responses & Themes \\
\hline l & $\begin{array}{l}\text { What do you know } \\
\text { about iSTEM? }\end{array}$ & 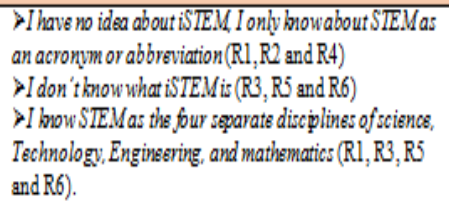 & $\begin{array}{l}\text { Concaption of } \\
\text { iSTEM }\end{array}$ \\
\hline 2 & $\begin{array}{l}\text { Do you knowhow } \\
\text { to train the learners } \\
\text { to beprepared to teach } \\
\text { the iSTEM course? }\end{array}$ & 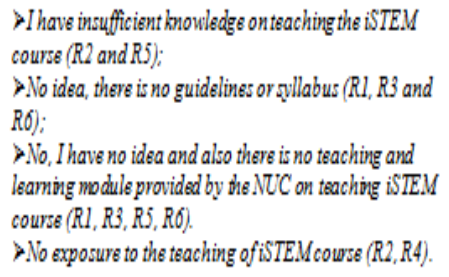 & $\begin{array}{l}\text { Pedagogical } \\
\text { Knowledge }\end{array}$ \\
\hline 3 & $\begin{array}{l}\text { What is your current } \\
\text { syllabus? }\end{array}$ & $\begin{array}{l}\text { Our current syllabus in Nigeria is still on teaching } \\
\text { individual disciplins } \\
(R 1, R 2, R 3, R 4, R 5 \text {, and } R O) \text {. }\end{array}$ & $\begin{array}{l}\text { Curricula } \\
\text { Knowledge }\end{array}$ \\
\hline 4 & $\begin{array}{l}\text { What is your teaching } \\
\text { strategy? }\end{array}$ & $\begin{array}{l}>\text { Our cument teaching practice in Nigeria is based on the } \\
\text { single discipline instruction (R1, R2, R3, R4, RS, and } R O) \text {. }\end{array}$ & $\begin{array}{l}\text { Instructional } \\
\text { Strategy }\end{array}$ \\
\hline 5 & $\begin{array}{l}\text { Are you still teaching } \\
\text { in this way? }\end{array}$ & $\begin{array}{l}\text { Absolutelyyes, no idea about combining two or more } \\
\text { disciplines (R1, R2, R3, R4,R5, and } R 6) \text {. }\end{array}$ & $\begin{array}{l}\text { Pedagogical } \\
\text { Knowledge }\end{array}$ \\
\hline 6 & $\begin{array}{l}\text { Are there any neads } \\
\text { for the integrated } \\
\text { STEM courses in } \\
\text { making the teaching } \\
\text { and learningmore } \\
\text { connected? Why? }\end{array}$ & $\begin{array}{l}\text { Yes, sure. But no idea how to integrate the discipline } \\
\text { together (RI, R3, andR4) } \\
>\text { yes, defnitely. I don't hrow how it can be integrated ( } R 2 \\
\text { and RO) } \\
\text { >of course, yes but the teachers in Nigeria were not } \\
\text { exposed to the integration of several STEMdisciplines ( } R 2 \\
\text { and } R 5 \text { ) } \\
>\text { I feel urprepared to connect STEMfields as there are no } \\
\text { guidelines provided (R4). }\end{array}$ & Content Knowledge \\
\hline 7 & $\begin{array}{l}\text { Do you think a } \\
\text { trainingmodule is } \\
\text { needed forteaching } \\
\text { iSTEM course? }\end{array}$ & $\begin{array}{l}>Y_{6 s,} \text { definitely }(R 1, R 2, R 4 \text {, and } R \sigma) \\
\left.>Y_{6 s,} \text { sure it is needed ( } R 3 \text { and } R 5\right)\end{array}$ & $\begin{array}{l}\text { Curricula } \\
\text { Knowledge }\end{array}$ \\
\hline
\end{tabular}

\section{DISCUSSION AND CONCLUSION}

The typical responses identified in this study were based on the three key issues recorded during the interviews with regards to the conception of iSTEM, the teaching of the iSTEM course, and the need for iSTEM teaching and learning. Overall, all the respondents indicated that they have no idea or knowledge about the concept of iSTEM education. This finding is related to the study of Okpala [1], that the teachers in Nigeria are not exposed to integrated STEM and were only receiving training in the single and separate fields of STEM. Consequently, $100 \%$ of the respondents recommended the need for teaching the iSTEM course and to be incorporated into the Nigerian educational system. In addition, this finding is in line with the study of Ugo [44], that call for action to integrate STEM disciplines into the Nigerian curriculum. Conclusively, all the respondents expressed a need for a training module for teaching iSTEM course in making the teaching and learning more connected. Hence, the outcomes of this study provided a strong justification for the researchers of this study to design and develop iSTEM training module as a guideline for the pre-service mathematics teachers to be prepared for the teaching of an iSTEM course.

The overall outcomes of this study indeed provide evidence and cover two issues. The first issue relates to the need for iSTEM course training. The second is teaching module to increase the ability for making the teaching strategy more connected. This would also help in preparing the pre-service mathematics teachers' readiness in teaching iSTEM course. Looking at the nature and status of the respondents, the findings of this study are worth generalisation for the need of iSTEM training course in Nigeria. Conclusively, the findings for this study pave the way for the need to conduct an elaborative study about the iSTEM course training and the development of iSTEM teaching module in Nigeria.

\section{A. Suggestion for Further Study}

This study suggests that a future study could be explored and designed to involve both the qualitative and quantitative research methods.

\section{REFERENCES}

1. Okpala, P.N., Reforms in Science, Technology, Engineering and Mathematics (STEM) Education, in Keynote Address 54th Science Teachers Association of Nigeria (STAN). 2012

2. Jayarajah, K., R.M. Saat, and R.A.A. Rauf, A review of science, technology, engineering \& mathematics (STEM) education research from 1999-2013: A Malaysian perspective. Eurasia Journal of Mathematics, Science \& Technology Education, 2014. 10(3): p. 155-163.

3. Kalolo, J.F., Re-Aligning Approaches for Successful Implementation of STEM Education in Today's Elementary Schools in Developing Countries: Policy Commitments and Practices. Journal of Education and Literature, 2016. 4(2): p. 61-76.

4. Dooley, A., et al., Analysis of a STEM Education Professional Development Conference for Pre-service Educators. 2017, University of Missouri-Saint Louis.

5. Honey, M., G. Pearson, and H. Schweingruber, STEM integration in K-12 education: Status, prospects, and an agenda for research. 2014: National Academies Press Washington, DC, USA.

6. Evans, E.M., Preparing elementary pre-service teachers to integrate STEM: A mixed-methods study. 2015, Northern Illinois University: Dekalb, Illinois, USA.

7. Heba, E.-D., et al., Context of STEM Integration in Schools: Views from In-service Science Teachers. 
Eurasia Journal of Mathematics, Science and Technology

8. Capraro, R.M. and S.W. Slough, Why PBL? Why STEM? Why now? An introduction to STEM projectbased learning, in STEM Project-Based Learning. 2013: pp. 1-5. Boston, MA, USA.

9. Jacobs, H.H., Interdisciplinary curriculum: Design and implementation. Association for Supervision and Curriculum Development. 1989, 1250 N. Pitt Street, Alexandria, VA 22314 USA: ERIC.

10. Frykholm, J. and G. Glasson, Connecting science and mathematics instruction: Pedagogical context knowledge for teachers. School Science and Mathematics, 2005. 105(3): p. 127-141.

11. Koirala, H.P. and J.K. Bowman, Preparing middle level Problems and possibilities. School Science and Mathematics, 2003. 103(3): p. 145-154.

12. Hassan, M.N., et al., Mathematics Curriculum Framework for Early Childhood Education Based on Science, Technology, Engineering and Mathematics (STEM). International Electronic Journal of Mathematics Education, 2018. 14(1): p. 15-31.

13. English, L.D., STEM education K-12: perspectives on integration. International Journal of STEM education, 2016. 3(1): p. 1-8.

14. National Research Council-NRC, STEM integration in K-12 Education: Status, Prospects, and Agenda for Research. 2014, Washington:: National Academies Press NGSS Lead States (2013) Next Generation Science Standards: For States, by States.

15. Stohlmann, M., T. Moore, and G. Roehrig, Considerations for Teaching Integrated STEM Education. Journal of Pre-College Engineering Education Research, 2012. 2(1): p. 28-34.

16. Goovaerts, L., Development and Assessment of iSTEM Competencies. 2019, KU Leuven: Belgium.

17. Shulman, L., Those who understand: Knowledge growth in teaching. Educational researcher, 1986. 15(2): p. 4-14.

18. Shulman, L., Knowledge and teaching: Foundations of the new reform. Harvard educational review, 1987. 57(1): p. 1-23.

19. Grossman, P.L., The making of a teacher: Teacher knowledge and teacher education. 1990, New York: The Teachers College Press.

20. Magnusson, S., J. Krajcik, and H. Borko, Nature, sources, and development of pedagogical content knowledge for science teaching, in Examining pedagogical content knowledge. 1999, Springer. p. 95132.

21. Shahali, M.H.E., et al., BITARA-STEM Training of Trainers' Programme: Impact on Trainers'knowledge, Beliefs, Attitudes and Efficacy Towards Integrated STEM Teaching. Journal of Baltic Science Education, 2015. 14(1): p. 85-96.

22. Appleton, K., How do beginning primary school teachers cope with science? Toward an understanding of science teaching practice. Research in science education, 2003. 33(1): p. 1-25.

23. Pratt, D.D., Conceptions of teaching. Adult education quarterly, 1992. 42(4): p. 203-220.

24. Richards, J.C., P.B. Gallo, and W.A. Renandya, Exploring teachers' beliefs and the processes of change. PAC journal, 2001. 1(1): p. 41-58.

25. Roehrig, G.H. and J.A. Luft, Constraints experienced by beginning secondary science teachers in implementing scientific inquiry lessons. International Journal of Science Education, 2004. 26(1): p. 3-24.

26. Breiner, J.M., et al., What is STEM? A discussion about School Science and Mathematics, 2012. 112(1): p. 3-11. Education, 2017. 13(6): p. 2459-2484. preservice teachers to integrate mathematics and science: conceptions of STEM in education and partnerships.

27. Bybee, R.W., The case for STEM education: Challenges and opportunities. 2013: National Science Teachers Association.

28. Moore, T., et al., Implementation and integration of engineering in K-12 STEM education. Engineering in precollege settings: Research into practice, 2014: p. 3560.

29. Koehler, M. and P. Mishra, What is technological pedagogical content knowledge (TPACK)? Contemporary issues in technology and teacher education, 2009. 9(1): p. 60-70.

30. Roberts, A. and D. Cantu. Applying STEM instructional strategies to design and technology curriculum. in PATT 26 Conference; Technology Education in the 21st Century; Stockholm; Sweden; 26-30 June; 2012. 2012. Linköping University Electronic Press.

31. Ring, E.A., Teacher Conceptions of Integrated STEM Education and How They Are Reflected in Integrated STEM Curriculum Writing and Classroom Implementation. 2017, University of Minnesota.

32. Furner, J.M. and D.D. Kumar, The mathematics and science integration argument: A stand for teacher education. Eurasia journal of mathematics, science \& technology education, 2007. 3(3): p. 185-189.

33. Ronis, D.L., Problem-based learning for math \& science: Integrating inquiry and the internet. 2007: Corwin Press.

34. Pang, J. and R. Good, A review of the integration of science and mathematics: Implications for further research. School Science and Mathematics, 2000. 100(2): p. 73-82.

35. Niess, M.L., Preparing teachers to teach science and mathematics with technology: Developing a technology pedagogical content knowledge. Teaching and teacher education, 2005. 21(5): p. 509-523.

36. Treacy, M.P. and J. O'Donoghue, Authentic integration of mathematics and science: a model for integrating Mathematics and Science in 2nd level education. 2012.

37. Nadelson, L.S., et al., Teacher STEM perception and preparation: Inquiry-based STEM professional development for elementary teachers. The Journal of Educational Research, 2013. 106(2): p. 157-168.

38. Ejiwale, J.A., Barriers to successful implementation of STEM education. Journal of Education and Learning (EduLearn), 2013. 7(2): p. 63-74.

39. Roehrig, G.H., et al., Is Adding the E Enough? Investigating the Impact of K-12 Engineering Standards on the Implementation of STEM Integration. School Science and Mathematics, 2012. 112(1): p. 31-44.

40. Creswell, J.W., Research design: Qualitative, quantitative, and mixed methods approaches. 2013, Far East Square, Singapore: Sage publications Asia-Pacific Pte Ltd.

41. Thomas, D.R., A general inductive approach for analyzing qualitative evaluation data. American journal of evaluation, 2006. 27(2): p. 237-246.

42. Mayring, P., Qualitative content analysis: Theoretical background and procedures, in Approaches to qualitative research in mathematics education. 2015, pp. 365-380 Klagenfurt, Austria.

43. Elo, S., et al., Qualitative content analysis: A focus on trustworthiness. SAGE open, 2014. 4(1): p. 1-10.

44. Ugo, E.A., Akpoghol T.V., Improving Science, Technology, Engineering and Mathematics (STEM) Programs in Secondary Schools in Benue State Nigeria: Challenges and Prospects. Asia Pacific Journal of Education, Arts and Sciences, 2016. 3(3): p. 6-16. 


\section{AUTHORS PROFILE}

Usman Galadima is a lecturer in the Department of Science Education at the Sokoto State University, Nigeria. He obtained his Master and Bachelor Degrees in Mathematics Education from Usmanu Danfodiyo University, Sokoto, Nigeria. $\mathrm{He}$ is currently a PhD student in the School of Education, Universiti Teknologi Malaysia (UTM). He has research interest in pedagogical content knowledge in teaching integrated STEM course, Mathematics Teacher Training and STEM literacy research.

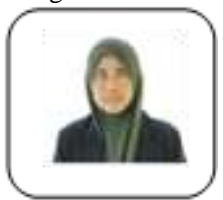

Zaleha Ismail is currently a professor at the Department of Educational Science, Mathematics and Multimedia Creative at Universiti Teknologi Malaysia. Her research interests and publications include teaching and learning of mathematics, mathematical thinking, statistical reasoning, mathematics teacher education, technology integration in mathematics education, STEM and engineering education. She has worked as a researcher, primary and secondary teacher educator, supervisor of graduate research and as a consultant to the Malaysian Ministry of Education for the STEM education and HOTS (high order thinking skills) projects.

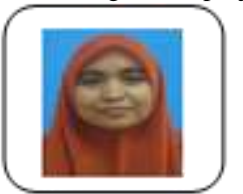

Norulhuda Ismail is a senior lecturer in the Department of Science, Mathematics and Creative Multimedia, School of Education, Universiti Teknologi Malaysia. She obtained her $\mathrm{PhD}$ from the UCL Institute of Education in 2015. Her current research interests include integrated STEM education, student teacher development and approaches to teaching mathematics 